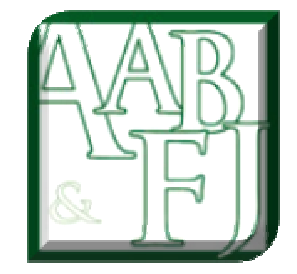

\title{
Auditing Litigation and Claims: Conflicts and the Compromise of Privilege
}

Harleen Kaur and Sandra van der Laan 1

\begin{abstract}
Auditing standards require an auditor to make various enquiries about liabilities in general this may entail consideration of potential litigations and claims that the audited entity may be facing. To perform this part of audit, the auditors will generally seek representation letters from lawyers of the company detailing an estimate prepared by management, confirmed by their lawyers through a representation letter, and then sent directly to the auditors.

This paper reviews the implications for the auditing profession of a case that involved auditors seeking such representation letters. The case involves litigation between the Westpac Banking Corporation and 789TEN Pty Ltd. While the Westpac case confirmed the legal position of the auditor in their task of collecting evidence in order to form an opinion in Australia, it highlights a significant anomaly under the law and should place the issue of solicitor's representation letters as audit evidence firmly on the agenda of policymakers.

This issue of the compromise of legal privilege during the conduct of an audit is also not confined to Australia: other common law jurisdictions, such as the UK and the US, have also sought to clarify the position of auditors when issues of the integrity of legal privacy privilege arise.
\end{abstract}

Keywords: Auditing standards; liabilities; representation letters; Westpac Banking Corporation; legal privilege.

JEL Code: M40

\footnotetext{
${ }^{1}$ Corresponding Author

Discipline of Accounting

University of Sydney Business School

Economics \& Business Building (H69)

University of Sydney. NSW. 2006

AUSTRALIA

P: +61 293516431

F: +61 293516638

E: sandra.vanderlaan@sydney.edu.au
} 


\section{Introduction}

Auditing standards prescribe both the principles and essential procedures that govern the audit process and the professional conduct of an auditor. In Australia, these standards carry the force of law when undertaking an audit under the Corporations Act 2001 (Cth). Australian Auditing Standards (ASA) require an auditor to make various enquiries about liabilities in general - this may entail consideration of potential litigations and claims that the audited entity may be facing. The auditors are required to enquire about all material legal matters and consider their possible impact on assets, liabilities, revenue and expenses. Auditors also have to ensure that the entity follows adequate accounting treatment of contingent liabilities along with ensuring appropriate disclosure in financial statements. To perform this part of an audit, the auditors will generally seek representation letters from lawyers of the company detailing an estimate prepared by management (confirmed by their lawyers) and then sent directly to the auditors.

This paper reviews the implications for the auditing profession of a case that involved auditors seeking such a representation letter. The case was initially heard in the New South Wales (NSW) Supreme Court and appealed to the NSW Court of Appeal ${ }^{2}$ with respect to the litigation between Westpac Banking Corporation and 789TEN Pty Ltd. The substantive litigation between the parties concerned a claim by 789TEN against Westpac for the removal of money from 789TEN's accounts with the bank without proper approval.

While the Westpac case confirmed the legal position of the auditor in their task of collecting evidence in order to form an opinion in Australia, it highlights a significant anomaly under the law and should place the issue of solicitor's representation letters as audit evidence firmly on the agenda of policymakers.

The paradox for auditors is that in order to perform their duties with the requisite care and skill of a professional required by auditing standards they are required to collect sufficient and appropriate evidence to form their opinion. However, in the course of gathering this evidence, when it entails solicitor's representation letters, auditors may compromise legal privacy privilege and as such adversely affect the litigation risk of the client. One solution would be not to gather this evidence in this way, however auditing standards mandate the appropriate procedures to collect evidence corroborating management assertions regarding litigation and claims under ASA 502 Audit Evidence - Specific Considerations for Litigation and Claims. Alternative, less reliable procedures may raise questions regarding the independence of the auditor or potentially open the way for litigation against the auditor.

This issue of the compromise of legal privilege during the conduct of an audit is not confined to Australia. Other common law jurisdictions, such as the UK and the US, have also sought to clarify the position of auditors when issues of legal privacy privilege arise. The Westpac case in Australia and similar developments internationally highlight the critical nature of this issue and create an urgency for the appropriate authorities to clarify the position for auditors in respect of legal privilege.

This paper differs from other accounts of this case (e.g. Fairweather \& Barker 2006; Law Council of Australia 2010) as it examines legal privilege through an auditor's lens demonstrated through the case concerning Westpac's application to prevent 789TEN to gain access to documents passing between Westpac's solicitors and its auditors. It highlights the structural impediments under the law for auditors. One the one hand, the law mandates through the auditing standards that information regarding litigation and claims must be collected and that externally-generated evidence (evidence gathered from sources other than the client) is more reliable. On the other hand, the law has confirmed that this process

\footnotetext{
${ }^{2}$ An application to appeal was made to the High Court of Australia. However, this application was rejected on the basis that there were insufficient prospects of success.
} 
constitutes a breach of legal privacy privilege essentially making this information 'public' and available to adverse parties in litigation.

\section{Case particulars}

The substantive case was initiated when 789TEN Pty Ltd (789TEN) sued Westpac Banking Corporation (Westpac) for a breach of authority or mandate regarding the payment of certain funds from its bank account held with Westpac. The bank denied responsibility for allowing the payment to be processed.

During the proceedings of this case, 789TEN's solicitors issued a subpoena for the production of documents including documents from Westpac to Henry Davis York (HDY) (Westpac's solicitors) requesting them to communicate directly with Westpac's auditors, PricewaterhouseCoopers (a typical form of solicitor' representation letter) and secondly the letters of response from HDY to the Westpac's auditors (the audit letters). These audit letters dealt with the Westpac's liability in terms of the 789TEN litigation and the estimate by Westpac's solicitors HDY regarding the financial settlement that may be incurred by Westpac as a result of the litigation.

Westpac sought an order from court to prevent 789TEN from accessing the audit letters on the basis that they were subject to legal professional privilege under the Evidence Act 1995 (NSW) (Evidence Act). To succeed, Westpac had to establish that the audit letters were a confidential communication or document and that the dominant purpose of the audit letters was either the provision of legal advice to it, in its capacity as a client ('legal advice privilege' under section 118 of the Evidence Act) and/or the provision of professional legal services to it, in its capacity as a client, relating to an Australian or overseas proceeding ('litigation privilege' under section 119 of the Evidence Act (Newman 2002)).

Section 118 of the Evidence Act headed as 'legal advice' provides:

"Evidence is not to be adduced if, on objection by a client, the court finds that adducing the evidence would result in disclosure of:

(a) a confidential communication made between the client and a lawyer; or

(b) a confidential communication made between 2 or more lawyers acting for the client; or

(c) the contents of a confidential document (whether delivered or not) prepared by the client or a lawyer;

for the dominant purpose of the lawyer, or one or more of the lawyers, providing legal advice to the client."

Section 119 of the Evidence Act headed as 'litigation' provides:

"Evidence is not to be adduced if, on objection by a client, the court finds that adducing the evidence would result in disclosure of:

(a) a confidential communication between the client and another person, or between a lawyer acting for the client and another person, that was made; or

(b) the contents of a confidential document (whether delivered or not) that was prepared;

for the dominant purpose of the client being provided with professional legal services relating to an Australian or overseas proceeding (including the proceeding before the court), or an anticipated or pending Australian or overseas proceeding, in which the client is or may be, or was or might have been, a party." 


\subsection{Decision at First Instance: Trial Judge ${ }^{3}$}

Without much dispute, the trial judge, Bergin J, accepted that the letters were confidential documents. However, her honour was not satisfied that the letters were privileged communications under the Evidence Act. Two issues were considered in this conclusion. First, whether the letters were prepared for the dominant purpose of HDY in providing legal advice to the bank, and second, whether the bank's auditors, PricewaterhouseCoopers (PwC), were agents of Westpac to receive the legal advice so provided.

Justice Bergin found that the dominant purpose of the letters was not to provide legal advice to Westpac but to enable the Westpac's auditors to know whether the director's estimate of a possible settlement figure could be relied upon. This would assist Westpac's auditors to audit the financial statements of Westpac and its controlled entities and hence did not satisfy the dominant purpose criteria.

Also, based on her reference of auditor independence requirements under the Corporations Act 2001 (Cth) (hereinafter Corporations Act), Justice Bergin rejected any agency relationship between the Westpac's solicitors and its auditors. As a consequence, the audit letters did not satisfy the purposes protected by the Evidence Act either under the legal advice privilege or litigation privilege.

\subsection{NSW Court of Appeal4}

The Court of Appeal agreed with Justice Bergin that the auditors were not the agents of Westpac for the purpose of receiving the letter from Westpac's lawyers. There was no evidence of agency agreement between Westpac and its auditors or that the auditors were appointed by Westpac to obtain information from its lawyers. The bank only authorised its lawyers to provide the required information to its auditors. The auditors used the information only for the purpose of performing its obligations under the Corporations Act with respect to the audit process.

Thus, the Court of Appeal supported the decision of the primary judge and concluded that s118 of the Evidence Act did not protect the letters.

The Court of Appeal again agreed with the decision of the trial judge on the matter of litigation privilege, in rejecting the application of s119 of the Evidence Act.

The court found that the dominant purpose of Westpac was not to seek legal advice of their lawyers in regards to the director's estimate of Westpac's contingent liability. It insisted that the Westpac's auditors PwC required the solicitor's representation letter, which could only be provided with Westpac's authorisation, for the purpose of carrying out its audit obligations. Thus, the court was satisfied that the evidence established that the letters would have been prepared irrespective of any intention on the part of Westpac to be provided with the legal opinion.

\subsection{Application for Special Leave to Appeal to the High Court of Australia ${ }^{5}$}

Westpac submitted to the High Court that the matter was of such public importance and the decision might result in that any litigant, who is subject to audit, can be required to produce documents which may disclose both the company's own view of its prospects in the litigation and the view of its solicitors. The Court of Appeal had also acknowledged this potential problem.

Westpac also asked the High Court to review the narrow view of Court of Appeal in defining 'professional legal service'. However, the court noted that:

\footnotetext{
3 789TEN \& Ors v Westpac Banking Corporation Ltd [2005] NSWSC 123

${ }^{4}$ Westpac Banking Corporation Ltd. v 789TEN Pty Ltd [2005] NSWCA 321

${ }^{5}$ Westpac Banking Corporation Ltd v 789TEN Pty Ltd [2005] HCA
} 
What was the dominant purpose for obtaining the letters for which legal professional privilege was claimed in this matter is essentially a question of fact. No point of general principle would conveniently fall for decision if the matter were special leave to be granted and there are in any event insufficient prospects of success to warrant a grant of special leave. ${ }^{6}$

Leave to appeal to the High Court was not granted. 789TEN was subsequently granted access to the documents on the basis of the decision from the NSW Court of Appeal.

\section{Implications of the Decision}

It was forcefully argued in the application to the High Court by Westpac's lawyers that if the decision as taken by the courts in the case were to stand, it would encourage as a standard practice in litigation against companies that were audited, the issuing of subpoena to an entity's auditor for the production of documents, such as were sought in this case. This situation would not be conducive to a fair hearing of matters in this type of litigation where adverse parties can gain access to details and 'estimates' of settlement amounts anticipated by defendant's lawyers. ${ }^{7}$

Such disclosure of details or estimates of the financial implications anticipated by the company with respect to the litigation for auditing purposes may affect the course of litigation. The disclosed estimate might vary from the amount the company might have offered to settle the matter thus making settlement negotiations more difficult.

Though the Court of Appeal recognised the problem and suggested legislative intervention as a possible remedy, at the same time the Court was not in favour of legislative change that would extend the rationale underpinning legal privilege or which would be different to that applying under general law with respect to litigation privilege.

Notwithstanding the abovementioned difficulties, audited entities cannot instruct their solicitors not to provide information about actual or pending litigation as required by their auditors so as to preserve the privileged nature of that information. This would result in the financial statements being subject to comment by the auditors or possibly result in the issue of a modified audit opinion.

\section{Auditing Litigation Contingencies}

The Australian Auditing Standards carry the force of law ${ }^{8}$ under the Corporations Act 2001 (Cth) and require auditors to collect 'sufficient and appropriate evidence' to verify the authenticity of claims by management. These include, among other things, assertions about liabilities and contingency or litigation reserves, current and likely litigation, enforcement matters and claims as well as legal advice provided about regulatory and transactional matters. The Westpac case demonstrates the difficult position of the auditor where the auditor's investigation fails to protect the integrity of legal privacy privilege. The situation gives rise to the possibility of information collected by the auditor in the course of the audit being subpoenaed by adverse parties involved in litigation, as was the case here, and places

\footnotetext{
${ }^{6}$ Westpac Banking Corporation Ltd v 789TEN Pty Ltd [2005] HCA Trans 1044

${ }^{7}$ Westpac Banking Corporation Ltd v 789TEN Pty Ltd [2005] HCA

${ }^{8}$ Until the Corporate Law Economic Reform Program Number 9 (CLERP 9) Act 2004, compliance with the standards was only mandatory for members of the Institute of Chartered Accountants of Australia and CPA Australia. This Act, among other things enacted provisions to give the auditing standards the same legal status as accounting standards and make their application mandatory for all registered company auditors (Austin \& Ramsay 2007).
} 
the client in a disadvantageous position in that action. Legal judgements ${ }^{9}$ against auditors clearly demonstrate that the most basic standard of "reasonable care and skill" expected of auditors is "adherence to professional standards in all aspects of an audit" (Gay \& Simnett 2010, p. 152).

While some discussion has occurred on the implications of this case from legal perspective (see for example Newman 2002), the perspective adopted here examines the implications through the auditor's lens, to demonstrate how the Westpac decision might affect the auditor's ability to gather sufficient and appropriate evidence and hence provide assurance as to whether the financial reports present a 'true and fair view' of an entity's wealth and progress.

\subsection{Evidence Collection and Evaluation}

According to the Corporations Act 2001 (Cth), it is the client's responsibility to prepare financial statements which present a 'true and fair view' of the state of affairs of the company in all material respects. It is the auditor who verifies the management claims and forms an opinion based on his/her collection of sufficient appropriate audit evidence. However, certain relevant audit evidence can only be obtained from the work of outside experts, as the auditors cannot corroborate certain management assertions without making such enquiries.

The Australian Auditing Standard (ASA 502) explicitly requires that an auditor ascertains and confirms contingent liabilities arising from pending legal matters and other actions against an entity. An important step in this process is to request that management send a letter of inquiry to the entity's lawyers, seeking comments on a list of pending or threatened litigation during the period, in order to acquire the requisite sufficient appropriate audit evidence. While these legal representation letters are prepared by management, a copy of the response is sent directly to the auditor to increase the reliability of the evidence. This response (or solicitor's representation letter) is an important facet in the evidence gathering exercise as it provides evidence as to the completeness of management assertions relating to liabilities arising from legal matters (Gay \& Simnett 2010). The Standard (ASA 502) further states that in case the auditor experiences a limitation of scope through an inability to obtain evidence directly from solicitors, he/she may need to consider modifying the audit opinion. Although the Standard asks the auditors to consider whether alternative audit procedures can provide further audit evidence, it maintains that if the auditor still considers it insufficient or inappropriate, they should modify the audit opinion accordingly.

Auditors are left in the difficult situation that by complying with auditing standards they might breach their client's legal privacy privilege. However, failing to follow the standards leaves auditors open to litigation themselves. Following the auditing standards has been the minimum standard for professional competence in exercising reasonable care and skill. ${ }^{10}$ Negligence claims against auditors arise from failing to adhere to professional standards (Gay \& Simnett 2010). However, as the Westpac case demonstrates, another segment of law, the Evidence Act and the case law that relies on its provisions, do not provide sufficient protection to auditors' work product to ensure appropriate access to required information without causing any undue harm either to the client or to its solicitors.

If disclosure of sensitive information to third party lawyers as a result of the audit process becomes commonplace then it will place audit clients in a situation in which they must choose between their right to confidential legal counsel and their responsibility and interest in cooperating fully with auditors to ensure appropriate accounting records and stakeholder confidence (Association of Corporate Counsel (ACC) in Wong 2006). Thus, if

\footnotetext{
${ }^{9}$ See Pacific Acceptance Corporation v Forsyth and Others (1970) 90 WN (NSW) 29.

${ }^{10}$ Pacific Acceptance Corporation v Forsyth and Others (1970) 90 WN (NSW)
} 
they decide to withhold information from auditors, they may have to forego a 'clean' or unmodified audit report.

The issue of the request of privileged information by auditors and it being subpoenaed by third parties is not new. However, in the past, attempts to intrude into the lawyeraccountant communications through solicitor's representation letters were rare. Erbstoesser and Matson (2003) suggest that this might be out of the traditional respect for the confidentiality of communications to which these professions were routinely participants. More recently, it has become increasingly common for adverse party lawyers to seek access to this type of information (McKenna 2008), and the Westpac judgment clearly opens the door for parties engaged in civil litigation against companies that have a commercial or statutory obligation to communicate with their auditors or regulatory authorities about their financial position to obtain access to sensitive information (Pickering 2008).

\subsection{Auditor Independence and Work-Product Privilege}

During the court proceedings the trial judge made reference to auditor independence requirements required under the Corporations Act and rejected any agency relationship between Westpac's solicitors and its auditors. This raises concerns as to whether auditor independence requirements safeguard audit quality or thwart the auditor work-product privilege.

This increased risk of exposure of audit work to third parties underlines a contradiction: the auditing standards, as noted above, carry the force of law in Australia under the Corporations Act, and require the auditors to gather such evidence from external experts when required. Further, evidence gathered from external sources directly by the auditors is considered higher quality and safeguards the independence of the auditor, which is also required under the Corporations Act. However, in doing so, the auditor compromises legal privacy privilege, and maintaining independence therefore potentially comes at the price of either an unmodified opinion or a disadvantage in commercial litigation.

\subsection{Legislative Change or Auditing Standards Guidance}

Justice Tobias (Court of Appeal Judge) indicated the denial of privilege for the solicitor representation letters would have a deleterious practical consequence as such letters were a necessary incident in an audit process. ${ }^{11}$ Thus it would be more likely than not that a prudent auditor will require confirmation of management assertions regarding contingent liabilities from the company's solicitors, and that such information would be provided directly to the auditor. He therefore rejected the primary judge's suggestion where it was proposed that audit clients should prepare the letters excluding the privileged material because it is the privileged material that the auditors require.

However, despite the recognition of the problem highlighted in the courts through the Westpac case, nothing more than a suggestion to consider legislative change has resulted, along with the warning that legal privacy privilege should not be extended beyond its original rationale. There has been no guidance either by the courts, or by regulators or by the auditing profession about the way in which the auditors can ensure continuous availability of information required for the audit in respect of litigation and claims without compromising clients' legal rights.

If legislative changes are not made, or auditing standards in relation to the sufficiency and appropriateness of evidence regarding litigation and contingencies are not altered, then any client with litigation contingencies that wishes them to remain confidential risks a modified opinion due to a scope limitation.

\footnotetext{
${ }^{11}$ Westpac Banking Corporation Ltd. v 789TEN Pty Ltd [2005] NSWCA 321 at para 65.
} 
The Westpac case also raises the question as to whether such a form of external evidence (solicitor representation letters) is the only means by which the auditor can verify management claims regarding litigation. If the auditors instead rely on internal evidence then it further raises other concerns such as: is there any other internal evidence such as solicitor's direct communication with the clients available to the auditors and which can be considered sufficient and appropriate audit evidence? If yes, does disclosure to the auditor compromise legal privilege? Is any internal evidence as persuasive as the externally gathered solicitor's representation letters? If no, does that mean that any such internal evidence should not be relied upon in relation to litigation and claims? If yes, does the auditor need to provide further evidence if such internal evidence is subject to adequate internal controls to ensure its appropriateness, accuracy and objectivity?

\section{Auditing Litigation Contingencies}

It is important to ensure a free flow of information between a business and its auditors in order to successfully verify the management claims in the financial statements, especially in respect of verifying litigation contingencies. However, any decision that breaks the privilege of protection of information, which is sensitive but at the same time is vital in the audit verification process, might discourage audit clients from providing all relevant information to the auditors.

As noted earlier, the issue of the request of privileged information by auditors and it compromising legal privacy privilege is not new. Reviewing the recent progress on this issue in both the US and UK, it is clear that there has been little in the way of a reasoned or cohesive approach by way of response from the courts or from the legal or accounting professions.

\subsection{US position on privileged information and audit evidence}

"Eroding the auditor and attorney-client privilege will] chill communications between companies and their accountants and punish those who cooperate fully with their auditors."

\section{Association of Corporate Counsel (ACC) in Wong (2006)}

A number of legal cases in the US have raised concerns over the scope of the so-called 'auditor privilege'. It remains inconclusive in the US as to whether the records turned over to auditors, including sensitive legal documents, are for the eyes of the auditor only, or whether they can be subpoenaed by third parties (Reisigner 2006).

In 1989, both the American Institute of Certified Public Accountants (AICPA) and American Bar Association (ABA) issued new commentaries to guide their respective professions about lawyer's letters (solicitor's representation letters in Australia) to auditors. The ABA maintained that any disclosure of privileged information to the auditors, either by the client or counsel, does not waive privilege. In addition, it clarified that any such nonwaiver statement does not in any way interfere with the standards and procedures of the accounting profession in the auditing process. The AICPA then confirmed this stance of ABA by addressing this non-waiver issue through an interpretation of Statements on Auditing Standards (SAS) 12 Inquiry of a client's lawyer concerning litigation, claims, and assessments (AU Section 337, updated June 2009) (AICPA, 2009).

Notwithstanding the pronouncements of these authorities, subsequent decisions in the US courts have been inconsistent. Some have decided that the work-product doctrine 
precludes the discovery of audit reports. ${ }^{12}$ According to these courts, audit reports are not prepared in the ordinary course of business, but are prepared only because of the litigation and hence the work-product doctrine restricts their discovery. Some other US courts however found that the audit reports are not attorney work product and hence the work product does not apply ${ }^{13}$ (Barrett 2005).

A case from Texas, AES Wolf Hollow v. The Shaw Group (2005), Inc., reinforced concerns regarding this issue by allowing third party access to auditor privileged documents. Following almost a year of debate and deliberation, the Texas Supreme Court overturned Shaw's confidentiality and allowed AES access to Shaw's financial records in May 2006. A subsequent motion for rehearing by Shaw was also denied.

The once most obvious ground for protection of a lawyer's communication, the attorney-client privilege, is not viable for restricting discovery of lawyer's letters when information is disclosed to a third party, including auditors. Some States in the US recognise an accountant-client privilege and maintain that a disclosure, in itself is privileged, and does not constitute a waiver. Although this might be relief in at least some jurisdictions, it is limited in operation as no such accountant-client privilege is recognised in US Federal proceedings (Erbstoesser and Matson 2003).

More recently, the Association of Corporate Counsel (ACC) and the ABA formed a task force (Task Force) to reinforce their efforts to protect the attorney-client and auditor privilege. Reisigner (2006) outlines the various solutions being proposed by the Task Force. First, the idea of a 'limited waiver' to auditors was offered in an attempt to address this issue. However, since the majority of courts had earlier rejected this defense, concluding that any waiver of privilege to one party waives the privilege to all parties, making the information 'fair game' in discovery. Second, the Task Force proposed to forward the idea of 'common interest doctrine' whereby the auditors and their clients would not be adversaries, but would share a common interest in accurate financial reporting. The case of Merrill Lynch \& Co. v. Allegheny Energy Inc. ${ }^{14}$ saw a successful application of this doctrine. Finally, the Task Force sought to convince the regulators, the Securities Exchange Commission (SEC) and the Public Company Accounting Oversight Board (PCAOB) to set tighter guidelines on what auditors should ask to see, including privileged information, from their clients. However the PCAOB did not appreciate the proposition that they should tell the auditors not to look for certain records (Reisinger 2006).

It remains worth contemplating that while other authorities are increasingly concerned about this issue, the issuance of AICPA auditing interpretations in July 2007, despite providing extensive guidance on how to interpret lawyer responses to auditors, did not provide any guidance on how to ensure the protection of privacy of the information provided in lawyer response letters. The interpretation does consider the possibility of inclusion of specific non-waiver statements as a possible rescue option (AU Section 9337, June 2009 revisions). However based on past court decisions, this is not an option that an audit client could rely upon.

Despite the attempts by various authorities in the US to address the privacy privilege issues concerning the attorney-client privilege and the auditors, the 2007 case of United

\footnotetext{
${ }^{12}$ Tronitech, Inc. v. NCR Corp., 108 F.R.D. 655, 656 (S.D.Ind. 1985); Southern Scrap Material Co. v. Fleming, 2003 WL 21474516, * 9 (E.D.La. 2003); Honeywell Intern'l. Sec. Lit., 230 F.R.D. 293, 300 (S.D.N.Y. 2003); Merrill Lynch \& Co. v. Allegheny Energy, Inc., 2004 WL 2389822, * 4 (S.D.N.Y. 2004); Laguna Beach Co. Water Dist. v. Superior Court, 22 Cal. Rptr. 3d 387, 391 (2004).

${ }^{13}$ U.S. v. Gulf Oil Corp., 760 F.2d 292, 296-97 (Temp. Emer. Ct. App. 1985); U.S. v. El Paso Co., 682 F.2d 530, 543-44 (1982).

${ }^{14}$ Merrill Lynch \& Co. v. Allegheny Energy, Inc., 2004 WL 2389822, * 4 (S.D.N.Y. 2004)
} 
States v. Textron, Inc. et. al ${ }^{15}$, has reaffirmed the problem. Among other issues, the case involved privacy issues when Textron disclosed its tax workpapers to its independent auditor, Ernst \& Young (EY), to assist EY in determining whether Textron's contingent tax liability reserves satisfied Generally Accepted Accounting Principles (GAAP). The District Court concluded that Textron's tax workpapers were correctly protected by the 'attorney work product' doctrine, but the case was subsequently being appealed in the United States Court of Appeal (Segal 2009).

The Association of Corporate Counsel (ACC) and The Chamber of Commerce of United States of America (The Chamber) released a supporting document in favour of Textron Inc. and urged the Court of Appeal to decline the Internal Revenue Service's (IRS) attempt to access the privileged information in April 2008. They maintain that such an action would discourage prudent corporate conduct and would punish companies that turn to their lawyers for assistance in the realities of running a modern business. This document reinforced concerns which might arise from such decisions as this strategy might become a matter of policy in other similar situations. Additionally it argued that a company's honest revelations to auditors being open to scrutiny by all adverse parties, as well as the fear of the extension of this waiver of privilege to include all other privileged communications and information regarding litigation, not just the information required in the audit (Segal 2009).

In addition, the Task Force made explicit its intentions to forward a protocol by August of 2008 with an aim to encourage auditors as well as regulators to clarify what information auditors can legitimately expect to access and maintain the integrity of the legal privacy privilege. However, at the time of writing there remains no resolution.

\subsection{UK position on privileged information and audit evidence}

In recent years, in an effort to improve the reliability of audit evidence available to auditors, the UK regulators have reinforced the statutory duties of directors and employees to provide relevant audit information. In particular, the provisions of the Companies (Audit, Investigations and Community Enterprise) Act 2004 strengthened the rights of auditors. However, some concerns still remain regarding the information held by third parties, especially lawyers, who are entitled to legal professional privilege. Thus, tensions arise when privileged information, although material to the truth and fairness of financial statements, might be withheld from the auditors (Institute of Chartered Accountants of England and Wales (ICAEW) 2007).

The UK standard, ISA (UK and Ireland) 500 Audit Evidence, defines audit evidence as all the information used by auditors in arriving at the conclusions on which the audit opinion is based. Similar to most jurisdictions, it makes a broad generalisation that audit evidence is more reliable when it is obtained from independent sources outside the company.

In addition ISA (UK and Ireland) 501 Audit Evidence (Additional Considerations for Specific Items (Part B)) provides standards and guidance to auditors with respect to audit procedures for litigation and claims provisions and disclosures. Auditors are required to carry out procedures to verify any litigation and claims involving the entity, and which can have material affect on the financial statements. In so doing the auditor can engage in direct communication with the entity's legal counsel, in the form of a letter addressed to the counsel by the board.

However as it currently stands, the right of persons or organisations to consult a lawyer in confidence is held to represent a higher public interest need than the right of shareholders, markets or society as a whole to benefit from true and fair financial statements (ICAEW 2007). Consequently, the audit files (or workpapers) do not enjoy legal professional privilege.

${ }^{15}$ No. 1:06-cv-00198 (U.S.D.Ct. for the District of R.I., 2007) 
The AQF working committee of the Institute of Chartered Accountants of England and Wales (ICAEW) (2007) highlighted this contradiction. On one hand the lawyers are required to respect their client's right to privilege and hence not allow their client's interests to be undermined by inappropriate disclosure of privileged information. On the other hand they should not recommend to the board or individual directors to take any course of action that is likely to lead to a breach of the duties to prepare 'true and fair' financial statements, or a failure to ensure the provision of relevant information to auditors. As such, despite the fact that the communication of privileged information could jeopardise the privileged nature of advice, it does not absolve the directors from their responsibility to ensure that the auditor has access to relevant audit evidence.

This issue was canvassed in the House of Lords in the debate over the Companies (Audit, Investigations and Community Enterprise) Bill in 2004 when Lord Razzall pointed out that if auditors are prevented from obtaining relevant privileged information then there shall be endless company reports where the auditors would be required to qualify (modify) the accounts as they were unable to form an opinion regarding whether the financial statements present a true and fair view. However, it appears from that discussion that in the absence of any legal authority, the Lords believe that the disclosure of any such information to auditors in order for them to form a true and fair view would not prejudice the matter to which the information is related as the auditor need not publicise it to any other party (Lord Sharman in Lords Debates 2004).

However, the Lords missed the possibility of such information being subpoenaed by the adverse party to the litigation. In addition, it was not taken into account that UK law does not privilege the work of the auditor. Despite the identification of the potential for modified opinions, the current UK Companies Act (2006) has no provisions which provide protection to a claim for legal professional privilege which could be maintained in legal proceedings (ICAEW 2007).

Apparently this matter is still on the agenda in the UK as a recent Exposure Draft: ISA 501 (Redrafted) has proposed that it should be made clearer in paragraph 11 (b) that the auditor would need to modify the opinion in the auditor's report if a scope limitation with regards to litigation and claims exists.

A legislative change to protect legal professional privilege has also been proposed by the working group of Audit Quality Fundamentals . It hopes that some reform can be introduced into law so that, rather than the access of auditors to privileged information being restricted, auditors should be included within the scope of privilege. Their proposal extends to not only that the auditor's access is unrestricted, but the resulting audit working papers are also privileged and auditors would be subject to equivalent prohibitions on the disclosure of such information as would apply to lawyers. However, in the meantime it has been documented that auditors should not be held responsible for any instance of audit failure which may result from the impact of legal professional privilege on the availability of audit information (ICAEW 2007).

\section{Summary and Conclusions}

The Westpac $v$ 789TEN Pty Ltd case clearly demonstrates the current Australian position of the protection of legal privacy privilege when the Court of Appeal rejected the claims of Westpac that a solicitor representation letter to the auditor is privileged. The subsequent failure to grant leave to appeal to the High Court on this issue highlights that under current law, the matter is settled.

Arens et al. (2010) outline the conflicts that might arise owing to different responsibilities of lawyers and auditors with respect to common clients. They explain that 
whereas the auditors are responsible for determining adequate disclosure in financial statements, the lawyers are responsible for 'winning the case'. As such many lawyers, for the fear of losing confidentiality and prejudicing the client's defense claim, might provide a 'less than candid' response to the auditor (Peters 2006).

It is well-known to auditors that some lawyers may view the prospects of success in litigation with 'rose tinted glasses' (Peters 2006), and hence provide an unreasonably optimistic comment about a claim. To protect auditors from being held accountable for reliance on unsatisfactory solicitor responses, the provisions of ASA 508 as a whole provide that the auditors are entitled to expect responses from lawyers not to be wrong, false or misleading and deceptive. However, the issue of the protection of the privileged nature of these communications is critical for the auditor in both maintaining their independence and the integrity of the audit.

Verifying litigation and claims requires auditors to rely on the work of legal experts and obtain solicitors' representation letters, however by providing this information, clients' legal privacy privilege is compromised. The implications of the decision in the case of Westpac Banking Corporation v. 789TEN Pty Ltd leaves a rather important unresolved issue for the auditing profession. Australian authorities (both legal and accounting) have not made any real progress toward a satisfactory resolution of this issue.

In June 2006 a meeting of the Auditing and Assurance Standards Board (AUASB) considered a Board Summary Paper which identified issues concerning the need for guidance to address the issue of legal privacy privilege in the audit process. However, the AUASB argued that in the wake of uncertainties surrounding the Westpac decision, it was unable to determine a suitable form and content of audit guidance in this regard. It concluded by forwarding the idea of seeking legislative intervention as a preferred option and proposed to draft a letter to the Standing Committee of Attorneys-General (Parker 2006). However, despite this issue being 'on the table' and amendments being proposed in 2009 to the Corporations Act under the Corporations Amendment (Corporate Reporting Reform) Bill 2010 via a new section (310A), no regulatory ${ }^{16}$ or professional action has followed.

Additionally, Australian regulators and professional bodies are not alone in struggling with this conflict. Evidence from the US and the UK demonstrates that this issue is likely a global problem requiring leadership from influential international standard-setting bodies.

The case of Westpac v. 789TEN Pty Ltd highlights an important contradiction for auditors. Auditors are required under the Corporations Act to collect 'sufficient appropriate evidence' to be able to draw reasonable conclusions on which to base their opinion. That opinion assures users that the financial statements give a 'true and fair view' of the financial position and performance of an entity. However, verifying litigation and claims under prevailing law and standards presents impediments for auditors to fulfill their obligations without compromising their client's commercial position when litigation and claims exist.

\section{References}

American Institute of Certified Practising Accountants (AICPA) 2007, AU Section 9337Inquiry of a Client's Lawyer Concerning Litigation, Claims, and Assessments: Auditing Interpretations of Section 337, AICPA086 vol. 1, July, pp. 591-664.

Arens, AA, Shailer, G, Best, P \& Fiedler, B 2010, Auditing, Assurance Services and Ethics in Australia: An Integrated Approach, Pearson Australia, Sydney.

\footnotetext{
${ }^{16}$ There were several submissions of the 51 received on the Bill that indicated broad support for the changes. However, the submission from the Law Council of Australia spoke against the reforms as proposed. The Law Council recommended changes to the wording of the section (Law Council, 2010), however the relevant section (310A) failed to appear in any form in the amendments.
} 
American Institute of CPAs (AICPA) Statements on Auditing Standards (SAS) 12 Inquiry of a client's lawyer concerning litigation, claims, and assessments, viewed 4 October 2010, http://www.aicpa.org/Research/Standards/AuditAttest/DownloadableDocuments/AU00337.pdf.

Austin, R \& Ramsay, I (2007) Ford's Principles of Corporations Law, 13th Edition. Australia, LexisNexis Butterworths.

Association of Corporate Counsel and The Chamber 2008, Brief for Amici Curiae the Chamber of Commerce of the United States of America and Association of Corporate Counsel supporting Textron Inc. and in favor of Affirmance, Association of Corporate Counsel and The Chamber, viewed 4 October 2010, http://www.acc.com/legalresources/resource.cfm?show=771156.

Barrett, M 2005 'Attorney Audit Reports and the Work Product Doctrine' in Review: Insurance, Reinsurance, Managed Healthcare, Morris, Manning \& Martin, LLP, p. 4, viewed 11 October 2010, http://www.mmmlaw.com/assets/files/Insurance\%20Reinsurance\%20Review\%20Winte r\%202005.pdf.

Erbstoesser, E \& Matson, J 2003, 'Lawyer's Letter to Auditors', Chapter 8 in M John Sterba, $\mathrm{Jr}$ (ed.), Legal Opinion Letters - A Comprehensive Guide to Opinion Letter Practice, Aspen Publishers, New York.

Fairweather, D \& Barker, K 2006 'Are Solicitor's Representation Letters Safe from Disclosure', AMPLA News, No. 38, August pp. 1-3

Gay, G \& Simnett, R 2010, Auditing \& Assurance Services in Australia, $4^{\text {th }}$ Edition, McGraw-Hill Australia Pty Limited, Sydney.

Institute of Chartered Accountants of England and Wales (ICAEW) 2007, 'Audit Quality Fundamentals - Third Parties' Report of Institute of Chartered Accountants of England and Wales, July.

Law Council of Australia 2010, Exposure draft of the Corporations Amendment (Corporate Reporting Reform) Bill 2010 - section 310A, Submission to Treasury, The Australian Treasury, viewed 12 October 2010, www.treasury.gov.au/documents/1764/PDF/Law_Council_of_Australia.pdf.

Lords Debates 2004, House of Lords Debates over Companies (Audit, Investigations and Community Enterprise) Bill, NewStatesman, viewed 11 October 2010, http://yourdemocracy.newstatesman.com/parliament/companies-audit-investigationsand-community-enterprise-bill/HAN11254971.

McKenna, F 2008, The "Assault" On Privilege- A US Chamber Viewpoint (And Mine), Re: The Auditors, viewed 4 October 2010, http://www.retheauditors.com/2008/04/assaulton-privilege-uschamber.html widgetType $=$ BlogArchive \&widgetId=BlogArchive1\&action=toggle \&dir $=$ close\&toggle=YEARLY-1199167200000\&toggleopen=MONTHLY-1207029600000.

Newman, S 2002, Alert for Audited Entities: Solicitor's Representation Letters - Innocent Audit Tool or Time Bomb for Companies?, Cornwall Stoddart Articles, viewed 11 October 2010, http://www.cornwalls.com.au/article_solicitorsaudit.htm.

Parker, C 2006, GAAP Alert No. 25/2006, GAAP, viewed 15 September 2010, http://www.gaap.com.au/html/gaap_alert_archive.html.

Peters, S 2006, Representation letters for clients and their auditors - a continuing challenge for lawyers, Deacons, pp. 1-41, viewed 4 October 2010, www.deacons.com.au.

Reisinger, S 2006, Texas case raises galvanizing issue for GCs: Auditor Privilege, Corporate Counsel, viewed 11 October 2010, http://www.law.com/jsp/cc/PubArticleCC.jsp?id=1149510920618. 
Segal, M 2009, 'Tax Accrual Workpapers and the Discovery Process: Textron Provides Insight', Research in Accounting Regulation, vol. 21, iss. 1, pp. 56 - 59.

http://dx.doi.org/10.1016/j.racreg.2008.11.005

Wong, A 2006, The Wavering Future of Auditor Privilege, LawCrossing, viewed 11 October 2010, http://www.lawcrossing.com/article/1665/The-Wavering-Future-of-AuditorPrivilege/. 